\title{
Stability of milking order in goat over a long period (short communication)
}

\begin{abstract}
The aim of this paper was to assess if goat milking order was stabile over a long period and if milking order is influenced by horned ness, age, body weight, breed, social status and milk productivity.

Milking order was studied in three periods: the second half of 1999, and the first and second halves of 2000.

To verify the results statistically, a variance analysis (ANOVA), the least squares method and Spearman's rank correlation were used.

The observed milking order of goats was non-random and very similar in the two consecutive years. Milk yield correlated with the milking order in two of the three periods (higher-yielding goats entered the milking parlour first). Social status as well as age affected milking order only in one period (dominant and younger animals came to the milking parlour earlier). In one period it was observed that body weight influenced the milking order at a marginally significant level $(\mathrm{p}=0.0598)$. Heavier goats were milked before lighter ones.

It can be suggested, that milk productivity is the strongest predictor of the animal position in the milking order. However, habits seems to influence milking order stronger than measurable traits. The own results were compared with other studies on milking order in cattle, sheep and goats.
\end{abstract}

Key Words: Capra hircus, milking order, social behaviour

\section{Zusammenfassung}

Titel der Arbeit: Die Konstanz der Melkordnung bei Ziegen während einer langen Zeitperiode (Kurzmitteilung)

Ziel der vorliegenden Arbeit war es zu untersuchen, ob die Reihenfolge der Ziegen im Melkstand (Melkordnung) während einer langen Zeitperiode stabil ist und ob Hörner, Alter, Gewicht, Rasse, Rangordnung und Milchleistung die Melkordnung beeinflussen.

Die Untersuchungen wurden in drei Perioden durchgeführt: In der zweiten Jahreshälfte 1999 sowie im ersten und zweiten Halbjahr 2000.

Die statistische Auswertung der Daten erfolgte mittels Varianzanalyse (ANOVA), der Methode der kleinsten Quadrate sowie der Rangkorrelation nach Spearman. Die beobachtete Melkordnung war nicht zufällig und sehr ähnlich in den zwei aufeinanderfolgenden Jahren. Die Milchleistung korrelierte mit der Melkordnung in zwei der drei untersuchten Perioden (Ziegen mit einer hohen Milchleistung nahmen erste Plätze in der Melkordnung ein). Rangordnung und Alter beeinflussten die Melkordnung nur jeweils während einer Zeitperiode (dominante und jüngere Tiere kamen früher auf den Melkstand). In gleichfalls nur einer Periode bestand ein schwacher Einfluss der Körpermasse (schwerere Tiere nahmen die Melkplätze vor leichteren ein, p=0,0598).

Aus den Ergebnissen der vorliegenden Arbeit lässt sich schlussfolgern, dass die Milchleistung die Melkordnung bei Ziegen am stärksten beeinflusst. Allerdings scheinen individuelle Gewohnheiten die Melkordnung stärker als messbare Merkmale zu bestimmen. Die Ergebnisse der eigenen Untersuchungen wurden mit Arbeiten anderer Autoren über die Melkordnung bei Kühen, Schafen und Ziegen verglichen.

Schlüsselwörter: Capra hircus, Melkordnung, Sozialverhalten

\section{Introduction}

The order of moving to and from pasture has been observed as non-random in domestic bovids (e.g. DOBICKI et al., 2000). Also the milking order in cattle (e.g. BÜNGER and BÜNGER, 1978; STEFANOWSKA et al., 2000), sheep (e.g. 
KESZTHELYI and MAROS, 1992; WASILEWSKI, 1999) and goats (e.g. DONALDSON et al., 1967; MARGETÍNOVÁ et al., 2001) was reported as nonrandom. However, WILLEMS and LAMPO (1964) reported that milking order in cattle was stable over 10 years, while WASILEWSKI (1999) stated, that sheep milking order was not stable over 13 weeks. There is also no agreement between authors investigating milking order in the same species, if and how studied factors influenced it (e.g. WILLEMS and LAMPO, 1964; HIDARI et al., 1973; GERE et al., 2001).

Therefore, the aim of this research was to assess if domestic goat milking order was stable over a long period of time and, if it was influenced by such factors as hornedness, age, body weight, breed, social status and milk productivity

\section{Material and methods}

The White Improved breed and crosses of the White Improved with Boer goat were studied. Observations were carried out in the years 1999 and 2000 at the Agricultural Experimental Farm in Złotniki near Poznań, Poland. In Złotniki, the goats are kept indoors: they never go out into a pasture, and rarely use a grassy yard. The goats are milked twice a day (at ca 8:00 and 18:00 hours) in the side-by-side milking parlour with 12 milking stalls at the same side (Westfalia-Separator). Milk performance controls are carried out once a month. The age of the individuals subject to the study ranged from 1 to 10 years. Both horned and hornless goats were observed. The body weight of the animals depending on age and genotype ranged from 22 to $79 \mathrm{~kg}$. A direct observation method was used. In 1999 thirteen records of the milking order of 36 goats were taken between July and November. In the first half of 2000 (April-June) 28 goats were milked and in this period the milking order was recorded 37 times. In July the group of milked goats was enlarged to 35. In the second half of 2000 (JulyNovember) milking order was recorded 26 times. Some goats came to the parlour voluntarily, the last ones usually had to be hurried, but the sequence of the animals was not arranged by the milker. The sequence in which the goats entered the parlour was recorded continually, the first group representing positions 1 to 12, second places 13 to 24 and third 25 to 36. Data for individuals, which were not milked at least at $60 \%$ of the recorded milkings were rejected. The average positions of the animals were used in further analyses.

The milk yield was recorded once a month during milk performance controls. Observations on social behaviour were carried out in the years 1998-2001. One observation session lasted from 2 to $7 \mathrm{~h}$. The total number of hours of observations was 580. Continuous recording (ALTMANN, 1974) and sampling of all the occurrences of all social behaviours and such behaviours which could have social implications was carried out. The observed animals were individually marked with numbers about $30 \mathrm{~cm}$ high painted on the sides and rump with washable spray for animal marking. The observations were carried out in production conditions in technological groups arranged by workers of the goat-house. From observations of agonistic behaviour, a dominance index was calculated for each individual as a quotient of the number of individuals over which the observed one dominates in relation to the number of animals with which it gets into domination relations (after SAMBRAUS, 1975).

To determine the effect of the studied factors (hornedness, breed, age, dominance index, body weight and milk productivity) on the milking order, a variance analysis 
(ANOVA) according to the least squares method was used. Spearman's rank correlation was used to evaluate the effect of age, dominance index, body weight and milk productivity on the milking order, and also to assess relationships between the milking order in each period (SAS 1996).

\section{Results}

It was found that in all the three studied periods the milking order was not random and it remained stable over a long time as Spearman's rank correlation between the periods studied were very strong $(\mathrm{R} \geq 0.816, \mathrm{p}=0.0001$, Table 1$)$. Thus, the milking order observed for 1999 was similar to that for 2000. Also the sequence of animals milked in smaller group in the first half of 2000 was similar to the sequence in bigger group in the second half of the same year. Breed and hornedness were factors with no significant influence on the milking order

Table 1

Spearman's rank correlation between milking order in studied periods (Rangkorrelation zwischen Melkordnung und Beobachtungsperioden)

\begin{tabular}{lll}
\hline period & $\mathrm{R}$ value & $\mathrm{n}$ \\
\hline $2^{\text {nd }}$ half of 1999 and 1st half of 2000 & $0.816^{* * *}$ & 23 \\
$2^{\text {nd }}$ half of 1999 and $2^{\text {nd }}$ half of 2000 & $0.889^{* * *}$ & 29 \\
1 st half of 2000 and $2^{\text {nd }}$ half of 2000 & $0.843^{* * *}$ & 21 \\
\hline$* * * p=0.0001$ &
\end{tabular}

The age of animals also appeared to have no significant influence on the milking order according to ANOVA results, but there significant correlation between these features was stated in one period (Table 2). Younger animals came to the milking parlour earlier than the older ones.

ANOVA revealed that social status had no effect on milking order, but a significant correlation of the dominance index and milking order was found in one period (Table 2). Goats with a higher social status came to the milking parlour earlier than animals with a lower social status.

Table 2

Spearman's rank correlation between milking order and studied factors (Rangkorrelation zwischen Melkordnung und untersuchten Merkmalen)

\begin{tabular}{lllll}
\hline period & age & dominance index & body weight & milk yield \\
\hline $2^{\text {nd }}$ half of 1999 & 0.004 & $-0.403^{*}$ & -0.301 & $-0.379^{*}$ \\
& 35 & 27 & 35 & 34 \\
1st half of 2000 & 0.218 & -0.275 & -0.188 & -0.311 \\
& 24 & 24 & 24 & 23 \\
$2^{\text {nd }}$ half of 2000 & $0.364^{*}$ & -0.313 & -0.063 & $-0.47^{* *}$ \\
& 33 & 33 & 33 & 29 \\
\hline
\end{tabular}

The number of animals is given below $R$ value ; * $p<0.05$; ** $p<0.01$

There was no significant correlation between body weight and milking order, but ANOVA showed that body weight influenced milking order in 1999 at a marginally significant level ( $\mathrm{p}=0.0598)$, as heavier animals were milked before than lighter ones.

According to ANOVA results, milk productivity appeared not to influence significantly milking order, but there was a significant correlation between the milk yield and milking order in the two periods studied. The goats with better milk performance entered to the milking parlour earlier than the ones with worse milk performance. 


\section{Discussion}

The milking order of goats reported in this paper was non-random. This is in agreement with the results of observations carried out by many authors on cattle (e.g. BÜNGER and BÜNGER, 1978; STEFANOWSKA et al., 2000), sheep (e.g. KESZTHELYI and MAROS, 1992; WASILEWSKI, 1999) and goats (e.g. DONALDSON et al., 1967; MARGETÍNOVÁ et al., 2001). Moreover, the milking order was stable over a long period, thus it was very similar in the two consecutive years. This statement is in agreement with WILLEMS and LAMPO (1964) who reported the milking order in cattle to be stable over 10 years. On the contrary WASILEWSKI (1999) stated, that sheep milking order was not stable over 13 weeks.

No influence of hornedness on milking order was observed in this study. On the contrary MARGETÍNOVÁ et al. (2001) reported, that horned goats came to the milking parlour earlier than the hornless ones.

The breed of goat appeared to be a factor not influencing the milking order as reported in this paper. DONALDSON et al. (1967) stated, that Alpine goats entered the milking parlour earlier than Saanen ones. FERGUSON et al. (1967) reported, that Holstein cows were milked earlier than Red Danish. However, in the latter paper it cannot be considered as breed behaviour difference per se as Holstein cows were also preeminent to Red Danish for milk yield.

Age of goats correlated with milking order only in one period of this study (younger animals came to the parlour earlier). In the literature there is a lack of consistency as to whether age of the animal influences its milking order. Some authors state that age had no significant influence (HIDARI et al., 1973: cattle, GRÄSER-HERMANN and SAMBRAUS, 2001: sheep), but there are also reports, that older animals came earlier to the milking parlour [WILLEMS and LAMPO, 1964:cattle, MARGETÍNOVÁ et al., 2001: goats (only in one of 3 considered periods)]. Contrary results were reported by DONALDSON et al. (1967) in goats and by other authors (FERGUSON et al., 1967; GERE et al., 2001) in cattle; these authors observed younger animals coming earlier.

The social status influenced the milking order only in one period in this study. GUHL and ATKESON (1959) stated that bunt-order (dominance order) influenced milking order in such a way, that dominating cows came to the barn earlier. However, contrary results were obtained by DONALDSON et al. (1967) in goats and GERE et al. (2001) in cattle. SAMBRAUS and KEIL (1997) observed no relationship between these features in goats. No relationship between leadership and dominance in ruminants have also been reported (e.g. ESCÓS et al., 1993).

Body weight influenced milking order only in one period in this report, heavier animals entered first. GOLOVAN (1979 after NOWICKI and ZWOLIŃSKABARTCZAK, 1983) stated a similar relationship only in cows shortly after delivery, but GERE et al. (2001) observed that lighter cows entered earlier. HIDARI et al. (1973) reported that body weight had no significant influence on milking order in cows, though the leading cows in the first few batches were older and heavier than the other. In sheep, GRÄSER-HERMANN and SAMBRAUS (2001) obtained similar results: ewes' weight did not influence milking order.

Milking productivity was the strongest predictor of milking order in this study, although this relationship was not observed at significant level in one period. Many authors reported that higher-yielding animals came to the milking parlour earlier than the lower-yielding ones [in cattle: WILLEMS and LAMPO, 1964; FERGUSON et al., 
1967; GOLOVAN, 1979 after NOWICKI and ZWOLIŃSKA-BARTCZAK, 1983, in goats: SAMBRAUS and KEIL, 1997; MARGETÍNOVÁ et al., 2001, in sheep: GRÄSER-HERMANN and SAMBRAUS, 2001 (in one of three considered herds)]. Interestingly, GERE et al. (2001) stated that cows with lower milk productivity in the previous lactation entered earlier, while current lactation productivity had no influence on milking order. HIDARI et al. (1973) reported no influence of milk yield on milking order.

As has been shown above, in the case of all considered factors possibly influencing milking order there is no agreement between the authors. The highest consistency between reports exists in case of the influence of milk yield on milking order in dairy bovids. Animals with better milk performance entered earlier as they have stronger motivation to be milked because of the pressure in the udder. Inconsistency between reports existing in the case of the other factors could be partially explained by differences in conditions in which animals were kept and milked and possibly also with differences in methods of investigations. Anyway, probably there is no clear and universally binding relationship between the factors considered and milking order. The authors of this paper agree with those authors who suggest that milking order "seems to be influenced by habits more than by measurable traits" (SAMBRAUS and KEIL, 1997).

\section{Acknowledgements}

This study was financially supported in part by a grant received from the Polish State Committee for Scientific Research.

ALTMANN, J.:

\section{References}

Observational study of behavior: sampling methods. Behaviour, 49 (1974), 227-267

BÜNGER, L.; BÜNGER, U.:

Beobachtungen zur Melkordnung bei Kühen. Arch. Tierz., Berlin 21 (1978), 439-48

DOBICKI, A.; CHUDOBA, K.; NOWAKOWSKI, P.:

Variability in behavioral hierarchy of mixed beef cattle herd grazing mountainous pasture. (In Polish with English summary). Zesz. Nauk. AR Wroc. 375 (2000), 211-218

DONALDSON, S.L.; ALBRIGHT, J.L.; BLACK, W.C.; ROSS, M.A.; BARTH, K.M.: Relationship between entrance order and social dominance in dairy goats. Am. Zool. 7 (1967), 807

ESCÓS, J.; ALADOS, C.L.; BOZA, J.: Leadership in a domestic goat herd. Appl. Anim. Behav. Sci. 38 (1993),41-47

FERGUSON, R.S.; ALBRIGHT, J.L.; HARRINGTON, R.B.; BLACK, W.C.; DONALDSON, S.L.: Dairy cattle behavior into a milking area. Am. Zool. 7 (1967), 807-8

GERE, T.; HAMAR, G.; GERE, Z .:

Behaviour of the cows in the milking parlour. Príspevky 28. Etologickej konferencie, Račkova dolina. (2001), 49-50

GRÄSER-HERRMANN, CH.; SAMBRAUS, H.H.:

The social behaviour of East Friesian dairy sheep in larger groups. Arch. Tierz., Dummerstorf 44 (2001), 421-423

GUHL, A.M.; ATKESON, F.W.:

Social organization in a herd of dairy cows. Trans. Kans. Acad. Sci 62 (1959), 80-7

HIDARI, H.; MASATERU, K.; SUZUKI, S.:

The order of entry of cows into a milking parlour under loose-housing conditions. (In Japanese with English summary). Jap. J. Zootech. Sci. 44 (1973), 33-8

KESZTHELYI, T.; MAROS, K.:

Moving order in different group sizes of milking ewes. Appl. Anim. Behav. Sci. 35 (1992), 181-188

MARGETÍNOVÁ, J.; BROUČEK, J.; APOLEN, D.: 
Order of goats during automatic milking. (In Slovak with English summary). J. Farm. Anim. Sci. 34 (2001), 89-96

NOWICKI, B.; ZWOLIŃSKA-BARTCZAK, I.:

Farm animal behaviour. (In Polish). PWRiL, Warszawa (1983)

SAMBRAUS, H.H.:

Beobachtungen und Überlegungen zur Sozialordnung von Rindern. Züchtungskunde 47 (1975), 8-14

SAMBRAUS, H.H.; KEIL, N.M.:

Die Konstanz der Melkordnung von Ziegen in großen Gruppen. J. Anim. Breed. Genet. 114 (1997), 397-404

SAS ,1996. SAS - Users Guide. SAS Inst. Inc. Cary NC.

STEFANOWSKA, J.; PLAVSIC, M.; IPEMA, A.H.; HENDRIKS, M.M.W.B.:

The effect of omitted milking on the behaviour of cows in the context of cluster attachment failure during automatic milking. Appl. Anim. Behav. Sci. 67 (2000), 277-291

WASILEWSKI, A.:

Demonstration and verification of milking order in dairy sheep and its extent and consistency. Appl. Anim. Behav. Sci. 64 (1999), 111-124

WILLEMS, A.E.R.; LAMPO, P.:

Milking order in cattle. (In Dutch with English summary). Vlaams diergeneesh Tijdsschr 33 (1964), 75 82

Received: 2004-01-06

Accepted: 2004-02-25

Authors' address

MARCIN TADEUSZ GÓRECKI, PhD; Prof. JACEK WÓJTOWSKI, DSc

Department of Sheep and Goat Breeding

August Cieszkowski Agriculture University of Poznań

Słoneczna 1, Złotniki,

62-002 Suchy Las

Poland

E-Mail: $\underline{\text { marcing@owl.au.poznan.pl }}$ 